\title{
PENGARUH KOMBINASI PIJAT OKSITOSIN DAN ENDHORPIN MASSAGE TERHADAP INVOLUSI UTERUS PADA IBU POST PARTUM DI BPS DESY ANDRIANI,S.TR.KEB BANDAR LAMPUNG TAHUN 2018
}

\author{
ANI MELINAWATI ${ }^{1}$ \\ ${ }^{1}$ Prodi D4 Kebidanan, Fakultas Kedokteran, Universitas Malahayati
}

\begin{abstract}
ABSTRAK
Selama masa nifas alat-alat internal maupun eksternal berangsur-angsur kembali seperti keadaan sebelum hamil. Perubahan keseluruhan alat genetalia ini disebut Involusi (Dewi,2011). Komplikasi nifas adalah proses involusi uterus yang tidak berjalan dengan baik (subinvolusi uterus) dapat menyebabkan perdarahan hingga kematian ibu. Salah satu cara untuk mempercepat involusi uterus yaitu dengan melakukan kombinasi pijat oksitosin dan endhorpin massage. Kombinasi pijat ini dapat merangsang hormon oksitosin yang menyebabkan kontraksi uterus sehingga proses involusi bisa berjalan normal. Tujuan penelitian ini untuk mengetahui pengaruh kombinasi pijat iksitosin dan endhorpin massage terhadap perubahan involusi uterus pada ibu post partum di BPS Desy Andriani, S.Tr.Keb Bandar Lampung Tahun 2018
\end{abstract}

Jenis penelitian ini adalah kuantiatif dengan metode praeksperimen menggunakan pendekatan Static Group Comporison. Populasi dalam peneliian ini adalah 60 responden ibu Post Partum. Sampel dalam peneltian ini diambil melaui cara Accidental sampling,sampel berjumlah 40 orang yang terdiri dari 20 orang ebagai responden yang di intervensi dan 20 orang sebagai variabel kontrol. Instrumen penelitian yang digunakan berpa lembar observasi untuk mengamati penurunan fundus uteri pada hari ke 4 post partum. Analisis ang digunakan adalah analisa unvariat dan bivariat dengan menggunakan u Independent T-Test.

Hasil penelitian ini didapatka uji statistik nilai rata-rata involusi uterus pada ibu post patum dari 20 responden yang diberikan kombinasi pijat oksitosin dan endhorpin massage adalah 0,80 sedangkan nilai rata-rata involusi uterus pada ibu postpartum dari 20 responden yang tidak diberikam massage adalah 1,25 dengan $p$-value $=0,020<0,05$. Berdasarkan uji statistik tersebut dapat disimpulkan bahwa ada pengaruh kombinasi pijat oksitosin dan endhorpin massage terhadap involus uterus pada ibu post partum. Saran dari penelitian ini bidan dapat melakukan pemberian kombinasi pijat oksitosin dan endhorpin massage pada ibu post partum untuk membantu mempercepat involusi uterus sehingga meningkatkan mutu pelayanan.

Kata Kunci : Pijat Oksitosin, Endhorpin Massage, Involusi

Uterus 


\section{PENDAHULUAN}

Masa nifas adalah masa pulih kembali, mulai dari persalinan sampai alatalat kandungan kembali seperti sebelum hamil.Masa nifas (puerpurium) dimulai setelah kelahiran plasenta dan berakhir ketika alat-alat kandungan kembali seperti keadaan sebelum hamil. Masa nifas berlangsung selama kira-kira 6 minggu (Asih \& Risneni, 2016).

Ibu dalam masa nifas mengalami perubahan fisiologis. Perubahan-perubahan yang terjadi yaitu sistem kardiovaskular, denyut jantung, volume dan curah jantung meningkat setelah melahirkan karena terhentinya aliran darah ke plasenta. Pada sistem perkemihan terjadi kesulitan dalam buang air kecil selama 24 jam pertama karena setelah plasenta lahir, kadar hormon esterogen yang bersifat menahan air akan mengalami penurunan yang mencolok, keadaan ini menyebabkan diuresis. Pada sistem reproduksi terjadi proses involusi. Involusi uteri adalah mengecilnya kembali rahim setelah persalinan kembali kebentuk asal. Kurangnya kontraksi uterus yang adekuat pada masa nifas dapat menghambat proses involusi uterus menyebabkan subinvolusi rahim, yang dapat mengakibatkan komplikasi. Pada subinvolusi terjadi kegagalan uterus untuk mengikuti pola normal involusi/proses involusi rahim tidak berjalan sebagaimana mestinya, sehingga proses pengecilan uterus terhambat. Faktor penyebab sub- involusi, antara lain: sisa plasenta dalam uterus, endometritis, adanya mioma uteri (Prawirohardjo, 2008). Pada pemeriksaan bimanual di temukan uterus lebih besar dan lebih lembek dari seharusnya, fundus masih tinggi, lochea banyak dan berbau, Uterus tidak berkontraksi dan tidak jarang terdapat pula perdarahan baik berupa perdarahan primer maupun sekunder. (Prawirohardjo, 2008).

Subinvolusi

uterus

menyebabkan kontraksi uterus menurun sehingga pembuluh darah yang lebar tidak menutup sempurna, sehingga pendarahan terjadi terus menerus, menyebabkan permasalahan lainya baik itu infeksi maupun inflamasi pada bagian rahim terkhususnya endromatrium. Sehingga proses involusi yang mestinya terjadi setelah nifas terganggu.

Jurnal Ilmu Kedokteran Dan Kesehatan, Volume 5, Nomor 3, Juli 2018
Namun, kontraksi rahim dapat ditingkatkan dengan pemberian oksitosin. Oksitosin dapat diperoleh dengan berbagai cara baik melalui oral, intra- nasal, intra muscular, maupun dengan pemijatan yang merangsang keluarnya hormon oksitosin. Oksitosin dapat dirangsang dengan melakukan pijat, teknik pijat yang dapat merangsang pelepasan hormon oksitosin termasuk pijat oksitosin dan pijat endorphin. Pijat oksitosin adalah tindakan pijat bagian tulang belakang (vertebra) mulai dari nervus costa ke 5-6 sampai scapula yang akan mempercepat kerja saraf parasimpatis untuk menyampaikan perintah ke otak bagian belakang untuk menghasilkan oksitosin. Pijat endorphin adalah teknik sentuhan dan pijatan ringan untuk memberikan rasa tenang dan kenyamanan yang dapat meningkatkan pelepasan oksitosin dan hormon endhorpin. Jadi, ketika pijat endorphin diberikan kepada ibu post partum, dapat memberikan rasa tenang dan kenyamanan yang dapat meningkatkan respon hipotalamus dalam memproduksi hormon oksitosin yang dapat meningkakan proses involusi uterus.

Berdasarkan penelitian yang dilakukan sebelumnya oleh Hamranani dengan judul pengaruh pijat oksitosin terhadap involusi uterus pada ibu postpartum dengan persalinan lama di rumah sakit wilayah kabupaten klaten Analisa yang dilakukan adalah ada hubungan yang bermakna antara pijat oksitosin dengan involusi uterus yang ditunjukkan dengan nilai $p<0.05$ dan kelompok tanpa pijat oksitosin akan mempunyai resiko 5 kali lebih besar untuk mengalami involusi uterus tidak normal dibandingkan kelompok dengan pijat oksitosin, hal ini ditunjukkan dengan nilai RR $5.250 \quad(1,975 ; 13,956)$. Data ini menunjukkan bahwa tindakan pijat oksitosin perlu dilakukan pada ibu post partum, terutama pada hari 1-3 untuk merangsang keluarnya hormon oksitosin. Gabungan pijat oksitosin-endhorpin massage sangat efektif, kombinasi menyebabkan dampak yang lebih signifikan pada proses involusi uterus karna pijat dilakukan di seluruh jaringan ikat akan meningkatkan kadar beta- endorphin dan oksitosin, ibu akan rileks sehingga mengurangi stres dan hormon oksitosin akan diproduksi tanpa inhibitor. Selanjutnya, pijat akan memicu 
hipofisis anterior untuk mensekresikan endorfin yang menghailkan sensasi nyeri berkurang dan tubuh akan merasa santai,yang akan meningkatkan pelepasan hormon oksitosin yang bertindak untuk meningkatkan kontraksi uterus.(Sari N,et al 2017) .

Sehubung dengan itu maka peneliti tertarik untuk meneliti lebih lanjut tentang pengaruh kombinasi pijat oksitosin dan endhorpin masassage terhadap involusi uterus pada ibu post partum di BPS Desy Andriani,S.Tr.Keb Bandar Lampung.

\section{METODE}

Jenis penelitian yang digunakan dalam penelitian ini adalah kuantitatif dengan pendekatan praeksperimen penelitian dengan melakukan kegiatan percobaan yang bertujuan untuk mengetahui gejala yang timbul akibat adanya perlakuan tertentu atau eksperimen tersebut (Notoatmodjo, 2012).

Rancangan penelitian yang digunakan adalah metode praeksperimen dengan pendekatan static Group Comparison. Pada penelitian ini diklasifikasikan 2 kelompok kemudian mengukur akibat atau pengaruhnya (Notoatmodjo,2012)

\section{Subyek Penelitian Populasi}

Populasi adalah wilayah generalisasi yang terdiri dari obyek atau subjek yang mempunyai kuantitas dan karakteristik tertentu yang ditetapkan oleh peneliti untuk dipelajari kemudian ditarik kesimpulannya (Hidayat, 2014). Populasi yang digunakan dalam penelitian ini adalah seluruh ibu postpartum di BPS Desy Andriani S.Tr.Keb pada bulan maret 2018 berjumlah 60 orang

\section{Sampel}

Sampel adalah bagian dari populasi yang ingin diteliti (priyono 2016). Sampel dalam penelitian ini berjumlah 40 orang yang teriri dari 15 orang sebagai responden yang di intervensi dan 20 orang sebagai varisbel kontrol.

\section{Teknik}

Sampel

Sampel

Pengambilan

dalam penetian ini menggunakan teknik pengambilan sampel secara teknik non probability sampling dengan cara acidental sampling yaitu pengambilan sampel secara aksidental(accidental) dengan mengambil kasus atau responden yang kebetulan ada atau tersedia disuatu tempat sesuai dengan konteks penelitian (Notoatmodjo,2012).

\section{HASIL PENELITIAN}

Karakteristik Responden

Tabel 1. Karakteristik Responden Berdasarkan Umur di BPS Desy Andriani,S.Tr.Keb Bandar Lampung

\begin{tabular}{|c|c|c|c|c|c|}
\hline $\begin{array}{l}\mathbf{N} \\
\mathbf{0}\end{array}$ & Umur & $\mathbf{N}$ & $\begin{array}{l}\text { inter } \\
\text { vens } \\
\text { i }\end{array}$ & $\begin{array}{l}\text { Ko } \\
\text { ntr } \\
\text { ol }\end{array}$ & $\%$ \\
\hline 1 & $\begin{array}{l}<20 \text { dan }> \\
35 \text { tahun } \\
\text { (beresiko) }\end{array}$ & 20 & 9 & 11 & $\begin{array}{c}50 \\
0\end{array}$ \\
\hline \multirow[t]{2}{*}{2} & $\begin{array}{l}20-35 \text { tahun } \\
\text { (tidak } \\
\text { beresiko) }\end{array}$ & 20 & 11 & 9 & $\begin{array}{c}50 \\
0\end{array}$ \\
\hline & Total & 40 & 20 & 20 & 100 \\
\hline
\end{tabular}

Berdasarkan Tabel 1 karakteristik responden berdasarkan umur di BPS Desy Andriani,S.Tr.Keb Bandar Lampung Tahun 2018 umur responden sama besar untuk katagori usia (<20 dan $>35$ tahun) $50 \%$ dan (20-35 tahun) $50 \%$.

\section{Karakteristik \\ Berdasarkan Paritas \\ Responden \\ Tabel 2. Karakteristik Responden Berdasarkan Paritas di BPS Desy Andriani,S.Tr.Keb Bandar Lampung}

\begin{tabular}{llcccc}
\hline No & Responden & \multicolumn{2}{c}{ Paritas } & N & $\%$ \\
& & \multicolumn{4}{c}{ Multi Primi } \\
\hline 1 & Intervensi & 7 & 13 & 20 & 50,0 \\
2 & Kontrol & 8 & 12 & 20 & 50,0 \\
& & & & & \\
\hline & Total & & & 40 & 100
\end{tabular}


Tabel 2. Uji Normalitas

\begin{tabular}{|c|c|c|c|c|}
\hline Variabel & $\begin{array}{c}\text { Nilai } \\
\text { Skew } \\
\text { ness }\end{array}$ & $\begin{array}{l}\text { Stand } \\
\text { ar } \\
\text { error }\end{array}$ & $\mid \begin{array}{c}\text { Hasil } \\
\text { pembag } \\
\text { ian }\end{array}$ & $\begin{array}{c}\text { Simpul } \\
\text { an }\end{array}$ \\
\hline $\begin{array}{l}\text { Involusi } \\
\text { Uteri } \\
\text { (kelompok } \\
\text { Intervensi) }\end{array}$ & $-0,294$ & $\begin{array}{c}0,51 \\
2\end{array}$ & $-\mathbf{0 , 5 7}$ & $\begin{array}{l}\text { Nor } \\
\text { mal }\end{array}$ \\
\hline $\begin{array}{l}\text { Involusi } \\
\text { Uteri } \\
\text { (Kelomp } \\
\text { ok } \\
\text { Kontrol) }\end{array}$ & $-\mathbf{0 , 2 5 3}$ & $\begin{array}{c}0,51 \\
2\end{array}$ & $-0,49$ & $\begin{array}{l}\text { Nor } \\
\text { mal }\end{array}$ \\
\hline
\end{tabular}

Berdasarkan Tabel 2 karakteristik responden berdasarkan paritas di BPS Desy Andriani,S.Tr.Keb Bandar Lampung Tahun 2018 paritas responden pada kelompok intervensi seabnyak 20 responden $(50 \%)$ dan kelompok kontrol $(50 \%)$.

\section{Analisis Univariat}

Distribusi Rata- Rata Perubahan Involusi Uteri pada Kelompok dengan Intervensi

Setelah dilakukan pengumpulan dan pengolahan data, didapatkan distribusi rata-rata perubahan involusi uteri pada kelompok intervensi sesudah Dilakukan Kombinasi Pijat Oksitosin Dan Endhorpin Masassage.

Rata-rata involusi uteri pada ibu yang diberikan intervensi adalah 0,80 dengan standar deviasi 0,52 Nilai terkecil yaitu 0,00 dan nilai maksimum adalah 2,00. Dari hasil estimasi interval dapat disimpulkan bahwa 95\% diyakini bahwa rata-rata involusi uteri pada ibu yang Dilakukan Kombinasi Pijat Oksitosin Dan Endhorpin Masassage, adalah diantara 0,55 $\mathrm{cm}$ sampai dengan $1,04 \mathrm{~cm}$.

\section{Distribusi \\ Rata- \\ Perubahan \\ Involusi Uteri pada Kelompok Kontrol}

rata

Rata-rata involusi uteri pada ibu yang tidak diberikan intervensi adalah 1,25 dengan standar deviasi 0,63 Nilai terkecil yaitu 0,00 dan nilai maksimum adalah 2,00 . Dari hasil estimasi interval dapat disimpulkan bahwa 95\% diyakini bahwa rata-rata involusi uteri pada ibu yang tidak Dilakukan Kombinasi Pijat Oksitosin Dan Endhorpin Masassage ( kelompok kontrol) adalah diantara $0,95 \mathrm{~cm}$ sampai dengan $1,55 \mathrm{~cm}$.
Tabel di atas menunjukkan hasil uji normalitas data, dimana diketahui seluruh data variabel menghasilkan nilai skewness yang dibagi dengan standar erornya adalah

$<2$, sehingga dapat dijelaskan bahwa seluruh variabel berdistribusi normal.

\section{Analisis Bivariat}

Setelah dilakukan uji normalitas data didapatkan hasil seluruh data variabel menghasilkan nilai skewness yang dibagi dengan standar erornya adalah $<2$, sehingga dapat dijelaskan bahwa seluruh variabel berdistribusi normal sehingga pengujian hipotesis dilanjutkan dengan menggunakan $\mathrm{uji}$ t- test Independent dengan keputusan uji statistik menggunakan taraf signifikan $\mathrm{p}<0,05$ maka dapat diketahui perbedaan pengaruh antara kombinasai pijat oksitosin dan endhorpin masage terhadap perubahan involusi uterus pada ibu post partum sebagaimana dapat dilihat pada tabel berikut:

Tabel 4 Perbedaan Perubahan Involusi Uterus Pada Kelompok yang Dilakukan kombinasai pijat oksitosin dan endhorpin masage dan Pada Kelompok Kontrol pada ibu post partum di BPS Desy Andriani,S.Tr.Keb Bandar Lampung Tahun 2018

\begin{tabular}{|c|c|c|c|c|c|c|c|}
\hline \multicolumn{2}{|c|}{ Variabel } & $\mathbf{N}$ & $\begin{array}{l}\text { Me } \\
\text { an }\end{array}$ & SD & $\begin{array}{l}S \\
\boldsymbol{E}\end{array}$ & $\begin{array}{l}P . \\
\text { Val } \\
\text { ue }\end{array}$ & $\begin{array}{l}\text { Seli } \\
\text { sih }\end{array}$ \\
\hline \multirow{7}{*}{$\begin{array}{l}\text { Invo } \\
\text { lusi } \\
\text { Uter } \\
\mathrm{i}\end{array}$} & Kelom & 4 & 0.8 & 0.5 & 0 . & 0.0 & 1.1 \\
\hline & & 0 & 0 & 2 & 1 & 20 & 7 \\
\hline & Interve & & & & 2 & & \\
\hline & & & & & & & \\
\hline & Kelom & & 1,2 & 0,6 & 0 , & & \\
\hline & & & 5 & 3 & 1 & & \\
\hline & Kontro & & & & 4 & & \\
\hline
\end{tabular}


Berdasarkan tabel 4.8 di atas dapat diketahui bahwa pada hasil analisis diperoleh jumlah rata - rata involusi uteri pada ibu yang diberikan intervensi adalah 0,80 dengan standar deviasi 0,52 sedangkan rata-rata involusi uteri pada ibu yang tidak diberikan intervensi adalah 1,25 dengan standar deviasi 0,63. Pada hasil uji statistik didapatkan nilai p-value $0,020<\square \quad 0,05$ maka dapat disimpulkan bahwa terdapat perbedaan yang signifikan rata- rata involusi uteri antara ibu yang dilakukan kombinasai pijat oksitosin dan endhorpin masage dengan yang tidak diberikan intervensi.

\section{PEMBAHASAN}

Rata - Rata Involusi Uteri Pada Ibu yang dilakukan kombinasai pijat oksitosin dan endhorpin massage. Berdasarkan hasil penelitian rata-rata involusi uteri pada ibu yang diberikan intervensi adalah 0,80 dengan standar deviasi 0,52 Nilai terkecil yaitu 0,00 dan nilai maksimum adalah 2,00. Dari hasil estimasi interval dapat disimpulkan bahwa 95\% diyakini bahwa rata-rata involusi uteri pada ibu yang Dilakukan Kombinasi Pijat Oksitosin Dan Endhorpin Masassage, adalah diantara $0,55 \mathrm{~cm}$ sampai dengan $1,04 \mathrm{~cm}$.

Involusi uterus merupakan pengecilan yang normal dari suatu organ setelah organ tersebut memenuhi fungsiya, misalnya pengecilan uterus setelah melahirkan. Involusi uterus adah mengecilnya kembali rahim setelah pesalinan kembali ke bentuk asal. Pijat oksitosin adalah pemijatan pada daerah tulang leher, punggung, atau sepanjang tulang belakang (vertebrae) sampai tulang costae kelima sampai keenam. Pijat oksitosin adalah tindakan yang dilakukan oleh suami pada ibu menyusui yang berupa back massage pada punggung ibu untuk meningkatkan pengeluaran hormon oksitosin. Pijat oksitosin yang dilakukan suami akan memberikan kenyamanan pada ibu, sehigga memberikan kenyaman pada bayi yang disusui. Oksitosin diproduksi oleh kelenjar pituitari posterior (neurohipofisis) (Rahayu, 2016).

$$
\text { Endorphin }
$$

Berasal dari kata "endogenous + morphine". Endorfin merupakan molekul protein, yang diproduksi oleh sel dalam sistem saraf dan bagian lain dari tubuh Anda. Secara keseluruhan ada kurang lebih dua puluh jenis hormon kebahagiaan. Meskipun cara kerja dan dampaknya berbeda beda, efek farmaologisnya sama. Diantara begitu banyak hormon kebahagiaan, beta endorfin paling berkhasiat, kerjanya lima atau enam kali lebih kuat dibandingkan dengan obat bius. Endorfin adalah polipeptida, yang mampu mengikat ke reseptor saraf di otak untuk memberikan bantuan dari rasa sakit yang di sekresi oleh kelenjar Hipofise. Endorphin merupakan hormon penghilang rasa sakit yang alami berkaitan dengan reseptor opioid dalam otak. Peran penting dari endorfin adalah bekerja dengan reseptor obat penenang yang dikenal untuk meringankan rasa sakit secara umum. Endorphine dihasilkan di otak Anda, saraf tulang belakang, dan ujung saraf lainnya. Tubuh memproduksi secara alami terutama pada saat berhubungan seksual, kehamilan, melahirkan, dan menyusui. Oksitosin memicu pelepasan Endorphin. Riset menunjukkan bahwa penggunaan obat- obatan dan opioid dalam otak dapat menurunkan kadar endorfin dan memicu terjadinya post partum blues.

Menurut pendapat peneliti adalah hasil penelitian pada ibu yang diberikan intervensi mengalami involusi uteri dengan rata - rata 0,80 . Penurunan involusi uterus teraba $1 \mathrm{~cm}$ biasanya terjadi pada post partum hari ke 6 dan 7 Hal ini disebabkan karena karakteristik responden dari 20 sampel yang diambil lebih banyak dalam katagori paritas dengan ibu primi dan multi hal ini disebabkan ketidaktauan ibu sehingga lebih kooperatif dan bisa bekerjasama saat dilakukan intervensi.dan pada ibu multi paritas sangat mempengaruhi involusi uterus, karena otot-otot yang terlalu sering teregang memerlukan waktu yang lama untuk kembali seperti keadaan normal.

\section{Rata - rata Involusi Uterus Pada Kelompok Kontrol \\ Hasil penelitian rata-rata involusi} uteri pada ibu yang tidak diberikan intervensi adalah 1,25 dengan standar deviasi 0,63 . Nilai terkecil yaitu 0,00 dan nilai maksimum adalah 2,00. Dari hasil estimasi interval dapat disimpulkan bahwa $95 \%$ diyakini bahwa rata-rata involusi uteri pada ibu 
yang tidak Dilakukan Kombinasi Pijat Oksitosin Dan Endhorpin Masassage ( kelompok kontrol) adalah diantara $0,95 \mathrm{~cm}$ sampai dengan $1,55 \mathrm{~cm}$.

Hasil penelitian ini sejalan dengan Nurmala Sari, (2017) yaitu rata-rata involusi uteri pada ibu yang tidak diberikan intervensi adalah 190,37 dengan standar deviasi $122,04 \mathrm{pg} / \mathrm{ml}$ dan yang diberikan intervensi adalah 223,50 dengan standar deviasi 127,16 pg/ml perbedaan efek pemijatan pada kelompok intervensi dan kelompok kontrol mempunyai perbedaan yang signifikan dengan $p<0.05$. Fundus uteri kira-kira sepusat dalam hari pertama bersalin. Penyusutan antara $1-1,5 \mathrm{~cm}$ atau sekitar 1 jari perhari. Dalam 10-12 hari uterus tidak teraba lagi di abdomen karena sudah masuk di bawah simfisi. Pada bukukeperawatan maternitas pada hari ke- 9 uterus sudah tidak teraba.

Involusi ligament uterus berangsurangsur, pada awalnya cenderung miring ke belakang. Kembali normal antefleksi dan posisi anteverted pada akhir minggu keenam (Asih dan Risneni,2016 h 67-68). Menurut asumsi peneliti banyak faktor yang mempengaruhi penurunan fundus uteri diantaranya adalah umur, paritas, dan mobilisasi dini.pada penelitian ini jumlah responden dengan katagori beresiko dan tidak beresiko pada kelompok kontrol sebanyak 20 responden dengan 11 kelompok beresiko dan 9 kelompok tidak beresiko. Untuk yang beresiko yaitu pada usia kurang dari 20 tahun dan lebih dari 35 tahun dimana pada usia kurang dari 20 tahun wanita belum siap secara psikis dan mental serta alat-alat reproduksi belum matang secara sempurna untuk mengandung. Pada usia lebih dari 35 tahun apada kondisi ini organ kandungan menua, jalan lahir tambah kaku, kondisi kesehatan ibu menurun serta fungsi rahim menurun salah satunya yaitu proses involusi uterus yang akan berjalan melambat. Kemudian utuk usia tidak beresiko yaitu 20-35 wanita produktif memiliki arti yakni suatu keadaan wanita yang telah cukup umur untuk bisa menghasilkan keturunan atau hamil.,karena pada usia tersebut organ tubuh wanita yang disebut rahim telah mampu untuk menghasilkan indung telur di dalam rahimnya dan bereproduksi. Masa reproduksi sehat, dalam arti masa yang paling aman untuk hamil dan melahirkan, adalah 20-35 tahun.

\section{Perbedaan Perubahan Involusi Uterus Pada Kelompok yang Dilakukan kombinasai pijat oksitosin dan endhorpin masage dan Pada Kelompok Kontrol pada ibu post partum}

Berdasarkan hasil analisis diperoleh diperoleh jumlah rata - rata involusi uteri pada ibu yang diberikan intervensi adalah 0,80 dengan standar deviasi 0,52 sedangkan ratarata involusi uteri pada ibu yang tidak diberikan intervensi adalah 1,25 dengan standar deviasi 0,63. Pada hasil uji statistik didapatkan nilai $p$ value $0,020<\square \quad 0,05$ maka dapat disimpulkan bahwa terdapat perbedaan yang signifikan rata- rata involusi uteri antara ibu yang dilakukan kombinasai pijat oksitosin dan endhorpin masage dengan yang tidak diberikan intervensi Pijat oksitosin adalah tindakan yang dilakukan oleh suami pada ibu menyusui yang berupa back massage pada punggung ibu untuk meningkatkan pengeluaran hormon oksitosin. Pijat oksitosin yang dilakukan suami akan memberikan kenyamanan pada ibu, sehigga memberikan kenyaman pada bayi yang disusui. Oksitosin diproduksi oleh kelenjar pituitari posterior (neurohipofisis) (Rahayu, 2016) Endorfin merupakan molekul protein, yang diproduksi oleh sel dalam sistem saraf dan bagian lain dari tubuh Anda. Secara keseluruhan ada kurang lebih dua puluh jenis hormon kebahagiaan. Hasil penelitian ini sejalan dengan Nurmala Sari, (2017) yang berjudul efektivitas kombinasi pijat oksitosin dan endorfin terhadap Involusi Uterus pada Ibu Nifas Normal Primipara. Hasil penelitian Ada Perbedaan tinggi fundus uterus ( TFU ) dari hari pertama hingga hari keempat pada kelompok kontrol ( $p=0,000)$. Ada perbedaan TFU sebelum dan sesudah pijat oksitosin $(p=0,000)$. Ada perbedaan TFU sebelum dan sesudha pijat endorfin $(p=0,000)$.Ada perbedaan TFU sebelum dan sesudah $\operatorname{kombinasi}(p=0,000)$. 
Menurut pendapat peneliti adanya perbedaan tinggi fundus uteri pada kelompok intervensi dan kontrol karena adanya efek oksitosin dan hormon endorphine disini sangat mebantu dalam proses involusi uteri. Dimana untuk proses involusi uterus pada ibu post partum yang diberikan terapi kombinasi pijat oksitosin dan endhorpin massage ternyata lebih cepat terjadi penurunan tinggi fundus uteri dibandingkan dengan ibu post partum yang tidak diberikan kombinasi pijat oksitosin dan endhorpin massage dimana terjadi penurunan timggi fundus uteri yang lebih lambat. Hal ini sejalan dengan teori bahwa pemberian pijat oksitosin dan endhorphin massage dapat merangsang produksi hormon oksitosin. sehingga dengan terjadinya involusi yang lebih cepat dapat memberikan kenyamanan pada ibu post partum, selain itu juga dapat merangsang pengeluaran asi ibu sehingga ibu bisa menyusui bayinya dengan rasa nyaman. Dalam penelitian ini dilakukan pengukur terhadap uterus, pengukuran yang dilakukan di mulai dari bagian pusat sampai ke bagian yang teraba uterus. Pengukuran yang dilakukan bukan untuk mengetahui berapa besar tinggi fundus uteri melainkan seberapa cepat penurunan uterus ibu. Pengukuran dilakukan menggunakan meteran (metlin) dimana dalam pengukuran alat yang digunakan kurang akurat dikarenakan bisa terdapat selisih dalam pengukuran. Sehingga untuk melakukan pengukuran sebaiknya dilakukan dari bagian fundus uteri sampai ke simpisis agar hasil pengukuran bisa lebih akurat.

\section{KESIMPULAN}

Berdasarkan hasil penelitian dan uraian pada bab sebelumnya maka dapat diambil

kesimpulan sebagai berikut :

1. Rata-rata involusi uteri pada ibu yang diberikan intervensi adalah 0,80 dengan standar deviasi 0,52

2. Rata-rata involusi uteri pada ibu yang tidak diberikan intervensi adalah 1,25 dengan standar deviasi 0,63

3. Ada perbedaan yang signifikan rata-rata involusi uteri antara ibu yang dilakukan kombinasai pijat oksitosin dan endhorpin masage dengan yang tidak diberikan intervensi ( $\mathrm{p}$ value $=$

$$
0,020<0,05 \text { ) }
$$

\section{Saran}

Adapun saran yang dapat penulis sampaikan pada penelitian ini adalah

sebagai

berikut :

$1 . \quad$ Bagi peneliti

selanjutnya

Diharapkan hasil penelitian ini dapat dijadikan sumber informasi dalam

mengembangkan penelitian lebih lanjut dengan mengendalikan variabel mobilisasi dini dan psikologis, menggunakan sampel yang lebih besar serta mengkaji involusi uterus dalam waktu yang lebih lama.

2. Bagi Tenaga

Kesehatan

Sebagai masukan kepada

tenaga

kesehatan khususnya bidan dalam pengembangan pelayanan kebidanan dalam mempercepat proses involusi uterus dengan memberi pijat oksitosin dan pijat endorfin selama masa nifas. Selain itu, bidan diharapkan juga mengajarkan pada keluarga tentang kombinasi pijat oksitosin dan pijat endorfin.

3. Bagi Prodi Kebidanan Universitas Malahayati

Diharapkan lebih menekankan kepada mahasiswa selain ada perubahan fisik

pada ibu selama masa kehamilan hingga persalinan juga ada perubahan psikologis, dimana perubahan psikologis ini juga akan berdampak pada perubahan fisik sehingga bidan harus lebih tanggap dengan tanda gejala kecemasan yang berlebihan karena jika tidak diatasi dapat menghambat proses persalinan.

4. Bagi Masyarakat (ibu nifas)

Sebagai informasi kepada masyarakat khususnya ibu nifas agar bias menerapkan pemberian intervensi kombinasi pijat oksitosin dan endorfin yang telah diajarkan oleh bidan agar 
dapat mempercepat involusi uterus. Khususnya pada ibu nifas baik yang reproduktif maupun yang sudah tidak reproduktif lagi. Sehingga akan memberikan rasa nyaman pada ibu sendiri.

\section{DAFTAR PUSTAKA}

Ambarwati, Eny Retna dan

DiahWulandari. 2010. Asuhan Kebidanan Nifas. Yogyakarta:Nuha Medika

Aprillia, Yesie. 2010.

Hipnostetri:Rileks, Nyaman, Aman Saat Hamil \& Melahirkan. Jakarta: Gagas Media

Asih, Yusari dan Risneni. 2016.

Asuhan Kebidanan Nifas dan Menyusui. Jakarta: Trans Info Media

Dewi, Lia Nanny Vivian danTri Sunarsih. 2013. Asuhan Kebidanan Pada Ibu Nifas. Jakarta: Salemba Medika

Hamranani, S. Pengaruh Pijat Oksitosin Terhadap Involusi Uterus Pada Ib Post Partum dengan Persalinan Lama di Kabupaten Klaten

Hidayat, Alimul Aziz. 2014. Metode Penelitian Kebidanan dan Teknik
Analisis Data. Jakarta: Salemba Medika

Morhenn V, Beavin LE, Zk PJ.

Massage Increases Oxytocin and Reduces Adrenocorticotropin Hormone in Humans

Notoatmodjo. 2012. Metodologi Penelitian Kesehatan. Jakarta: Rineka Cipta

Prawirohardjo,Sarwono. 2008. Ilmu Kebidanan. Jakarta: Bina Pustaka Priyono. 2016.

Metode Penelitian Kuantatif. Surabaya: Zifatma Publishing

Rahayu, Anik Puji. 2016. Kperaatan Maternitas. DEEPUBLISH Yogyakarta:

Sari N, et al. 2017. The Effectiveness Of Combination Of Oxytocin And Endorphin Massage On Uterine Involution InPrimiparous Mothers

Walyani, Siwi Elisabeth. 2017. Asuhan Kebidanan Masa Nifas dan Menyusui. Yogyakarta: PUSTAKABARUPRESS 